\title{
The Engagement Process: Examining the Evidence from Diverse Perspectives
}

\author{
Leslie K. Haugen \\ Anne S. Davis \\ Houston Baptist University
}

\begin{abstract}
In this paper we extend and elaborate an engagement process model, initially developed as an approach for improving the effectiveness of strategy implementation. Based on a qualitative analysis of an expansive set of studies, we find solid support for a three-component definition of engagement, add greater dimension and depth to the model's construct of social significance, and identify several factors associated with the development of an engaged workforce. We advance four propositions to guide future empirical research.
\end{abstract}

\section{Introduction}

In an earlier paper (Haugen \& Davis, in press), we took up the issue of why strategy implementation so often fails and concluded that the inherent separation between formulation and implementation necessitates building a bridge between the two processes. The approach we advocated to connect organizational thinkers (those who develop the long-term plans) and doers (those who put the plans in place) was to develop engaged members, individuals who are intellectually and emotionally invested in the organization and take action to transform it. In this study, we take a closer look at the engagement process to refine our model of transforming plan into action. Using a qualitative approach, we draw from an expansive set of studies to derive a finer-grained and more precise understanding. Our aim here is to move the scholarly inquiry forward and break new ground in terms of how we elaborate engagement so that organizations can purposefully work towards creating an engaged workforce and realize the benefits of well-executed strategy.

\section{A Working Definition}

From our initial work, we defined engagement as it relates specifically to strategy implementation as stemming from a deeply held conviction (intellectual) that the initiative is the right course of action, is preferred (emotional) over other courses of action, and directs behavioral change (action) to accomplish the initiative (Haugen \& Davis, in press). Engagement goes beyond inference or intellectual knowledge and says that actors will have a positive emotional attachment to the object/event, expressed as a preference for the object/event. Engagement also possesses an action. It suggests that because of the emotional attachment to the object/event, actors behave in ways to support the object/event.

Engagement as we conceive it is distinct from both commitment and involvement. Individuals may be committed to an object/event without feeling positive emotional 
attachment to it, as when commitment arises out of fear of reprisal or other kinds of negative consequences. Commitment also falls short on the action-behavior dimension of engagement since commitment may mean intention to behave but engagement means the behaviors are already in place. Engagement can be also distinguished from involvement. Involvement is based upon the exchange between the actor's contributions to the organization and the rewards provided by the organization (Gould, 1979), encompassing cognitive and behavioral components but lacking the emotional appeal of engagement (Staw, Sutton, \& Pelled, 1994).

\section{Methodology}

To evaluate the validity of our model, we analyzed a diverse sample of research to determine how engagement is characterized in a number of different contexts and applications; we were interested in theoretical, empirical and practitioner concepts and usages. In addition to the organization and social sciences, the education, philosophy and religion literatures were especially rich areas to mine and we built on such crossdisciplinary findings to inform our model. This last area was chosen to help ensure that we had a grounded understanding of the spirituality research, a topic that has recently begun to inform the organization and social sciences (Neal \& Biberman, 2003). Additionally, we carefully cultivated the reference section of each study obtained from the initial data collection phase for relevant content and expanded the sample accordingly to ensure that we were working from a sufficiently deep and broad set of literature.

We used a qualitative approach for analyzing data whereby engagement definitions and related themes were identified through both explicit as well as emergent processes. Initial categories that proved helpful in putting "flesh on the bones" of the construct (Miles \& Huberman, 1994, p. 27) included working definition, outcomes of engagement, key engagement process theories, and factors associated with the development of engagement. We also identified purely emergent themes, for example, how fear of failure and interpersonal competition can suppress engagement (Newman, 1989), and the notion that different people require different engagement drivers (D'Aprix \& Tyler, 2006; Harley \& Lee, 2005). Inductive coding was used to surface underlying categories, themes and patterns, and these became the "cornerstones" of the elaborated model proposed here (Strauss \& Corbin, 1998, p. 7). From this review and analysis, we developed four propositions that collectively articulate the engagement process.

Articles and studies were identified through targeted searches on multi-subject electronic databases, including Academic Search Complete, ATLA Religion, Business Source Complete, ERIC, Psychology and Behavioral Sciences Collection, Religion and Philosophy Collection, Professional Development Collection, PsycARTICLES and Psyclnfo databases; we also relied on print media for books and journals which had been excluded or embargoed from these databases. Of the one hundred and thirty articles examined, we selected forty-one for full analysis on the basis of meeting at least one of the following five categories: the articles identified intellectual, emotional and/or behavioral components as integral to change initiatives; or they possessed a 
recognizable strategy implementation perspective, an explicit engagement orientation, a spirituality focus, or the use of Appreciative Inquiry methodology to bring about organizational change. The first category was instrumental in confirming our working definition of engagement and its importance to strategic change while the second, third and fourth categories helped to better qualify the engagement process model, specifically the concept of social significance. The last set of studies provided insights into how an organization might develop and sustain an engaged workforce.

\section{Findings}

Our working definition was supported by the current study. Explicit and implicit definitions of engagement from both academic and practitioner research provided credible evidence that each of the three components - emotional, intellectual and behavioral - was necessary for the full meaning of engagement; twenty of the twentyeight studies described in Table 1, or just over $70 \%$ of the sample, reflect this understanding. In contrast, in those studies in which only one or two components were advanced as descriptive, the emphasis was most often placed on the cognitive realm rather than on either action/behavior or emotion. Consequently, the distinctiveness of the construct was diminished and thereby its power to uniquely explain and predict the phenomenon in question.

Several studies defined the term engagement or described what an engaged employee "looks" like. From the field of psychology, the work of William Kahn offers an early concept of engagement: "in engagement, people employ and express themselves physically, cognitively and emotionally during role performances" (1990, p. 694). May, Gilson, and Harter (2004), drawing on Kahn's work, provide additional support for the tripartite nature of engagement. They clearly delineate the active use of emotions and behaviors which they suggest distinguish engagement from job commitment or job involvement. Schaufeli and Bakker (2004) also express engagement as three-fold. They characterize it as a combination of vigor, expressed as high levels of energy (physical); dedication, expressed as enthusiasm, inspiration and pride (emotional); and absorption, the state of being fully intellectually engrossed in work (cognitive).

Other authors provide more visual imagery in the definition of engagement. For example, people who are engaged 'do not notice the passage of time - their hearts and minds are involved" (Haudan \& MacLean, 2002, p. 255). Such an individual has a heightened emotional connection to work (Gubman, 2004) and is "intellectually and emotionally committed to a particular job, so that he or she wants to give to that job what is known as discretionary effort" (Woodruffe, 2006, p. 29).

Two additional findings from this research bear mention. The first is the role of emotion in effecting change. While we expected to find ample evidence of intellectual and behavioral requirements for change (and were not disappointed in that regard), we did not anticipate the widespread discussions advancing emotion as pivotal to implementing change initiatives and transforming organizations of all types. The second, related finding is that many authors believe that there is an inherent order in the process of 
engagement with emotions coming first. Emotional buy-in or acceptance of the initiative precedes intellectual conviction to change, which in turn precedes behavioral change necessary for wholesale implementation of organizational change (Dutton, Dukerich, \& Harquail, 1984; Leana \& Barry, 2000; Lines, 2004; Miles, 2001). While not every study included here connected engagement or engagement-related constructs to strategic change, a majority - sixteen of the twenty-eight studies, or $57 \%$ of the sample understood this relationship to be the crux of the issue and developed models and explanations consistent with that logic.

Table 1. Conceptualizing Engagement

\begin{tabular}{|l|l|l|}
\hline \multicolumn{1}{|c|}{ Author } & Key Construct and Underlying Dimensions & Outcome Variable \\
\hline $\begin{array}{l}\text { Beer, } \\
\text { Eisenstat, \& } \\
\text { Spector } \\
\text { (1990) }\end{array}$ & $\begin{array}{l}\text { Commitment to change } \\
\text { - related to action (behavioral) component along } \\
\text { with socio-emotional component and consensus } \\
\text { (intellectual) }\end{array}$ & Strategic change \\
\hline $\begin{array}{l}\text { Bruch \& } \\
\text { Sattelberger } \\
\text { (2001) }\end{array}$ & $\begin{array}{l}\text { Emotional attachment } \\
\text { - requires emotional mobilization to create } \\
\text { lasting effects on the heads and hearts of } \\
\text { managers and employees (356) } \\
\text { (intellectual, emotional, behavioral) }\end{array}$ & Strategic change \\
\hline $\begin{array}{l}\text { D'Aprix \& } \\
\text { Tyler (2006) }\end{array}$ & $\begin{array}{l}\text { Engagement } \\
\text { - is a choice, which leads to learning, which in } \\
\text { turn leads to change in behavior (intellectual, } \\
\text { behavioral) } \\
\text { - choice of whether to engage or not is } \\
\text { influenced by employees' experiences in the } \\
\text { workplace } \\
\text { - is not high scores on an annual survey tool; } \\
\text { - is not a permanent state of employee } \\
\text { satisfaction and motivation }\end{array}$ & $\begin{array}{l}\text { Culture } \\
\text { change/organizatio } \\
\text { nal transformation }\end{array}$ \\
\hline $\begin{array}{l}\text { Dent, } \\
\text { Higgins, \& } \\
\text { Wharff } \\
\text { (2005) }\end{array}$ & $\begin{array}{l}\text { 'a framework of organizational values...that } \\
\text { promotes employees' experience of } \\
\text { transcendence through the work process } \\
\text { (behavioral, intellectual), facilitating their sense } \\
\text { of being connected to others in a way that } \\
\text { provides feelings of completeness and joy (p. } \\
\text { 627) (socio-emotional) }\end{array}$ & $\begin{array}{l}\text { Strategic change, } \\
\text { organizational } \\
\text { learning }\end{array}$ \\
\hline $\begin{array}{l}\text { Decision consensus } \\
\text { - increased consensus with more cognitive labor } \\
\text { such as provided by devil's advocate or other } \\
\text { forms of conflict (intellectual) } \\
\text { Decision commitment } \\
\text { - comes from greater consensus; positively }\end{array}$ & $\begin{array}{l}\text { Strategy } \\
\text { implementation }\end{array}$ \\
$\begin{array}{l}\text { Fryxell, \& } \\
\text { Judge } \\
(2000)\end{array}$ & \\
\hline
\end{tabular}




\begin{tabular}{|c|c|c|}
\hline & $\begin{array}{l}\text { affects acceptance of decisions (emotional) } \\
\text { - leads to greater effort (behavioral) }\end{array}$ & \\
\hline $\begin{array}{l}\text { Dutton, } \\
\text { Dukerich, \& } \\
\text { Harquail } \\
\text { (1994) }\end{array}$ & $\begin{array}{l}\text { Identification with the organization } \\
\text { - identity as an organization member is more } \\
\text { salient than alternative identities (emotional); } \\
\text { and } \\
\text { - self-concept has many of the same } \\
\text { characteristics that member believes define the } \\
\text { organization as a social group (values } \\
\text { alignment: intellectual); leads to } \\
\text { - organization citizenship behaviors: exertion on } \\
\text { behalf of the organization (behavioral) }\end{array}$ & $\begin{array}{l}\text { Missing link to } \\
\text { change initiatives }\end{array}$ \\
\hline $\begin{array}{l}\text { Gubman } \\
\text { (2004) }\end{array}$ & $\begin{array}{l}\text { Engagement } \\
\text { - associated with the heightened emotional } \\
\text { connection to a job and organization that goes } \\
\text { beyond satisfaction (p. 43) }\end{array}$ & $\begin{array}{l}\text { Individual-level } \\
\text { performance } \\
\text { improvement }\end{array}$ \\
\hline $\begin{array}{l}\text { Harley \& Lee } \\
\text { (2005) }\end{array}$ & $\begin{array}{l}\text { Engagement } \\
\text { - is } 2 \text {-way and organizations have to work to } \\
\text { achieve it } \\
\text { - consists of 'complex feelings and emotions' (p. } \\
\text { 25) } \\
\text { What an engaged employee looks like: } \\
\text { (1) positive about the job } \\
\text { (2) believes in and identifies with the } \\
\text { organization } \\
\text { (3) works actively to make things better } \\
\text { (4) treats others with respect and helps } \\
\text { colleagues to perform more effectively } \\
\text { (5) reliable and goes beyond the job } \\
\text { requirements } \\
\text { (6) acts with the bigger picture in mind, even at } \\
\text { personal cost } \\
\text { (7) stays current in his/her field } \\
\text { (8) looks for and is given opportunities to } \\
\text { improve organizational performance } \\
\text { (socio-emotional, intellectual, behavioral) }\end{array}$ & $\begin{array}{l}\text { Organizational } \\
\text { performance } \\
\text { improvement }\end{array}$ \\
\hline $\begin{array}{l}\text { Haudan \& } \\
\text { MacLean } \\
(2002)\end{array}$ & $\begin{array}{l}\text { Engagement } \\
\text { - 'the oxygen of accelerated learning and } \\
\text { enabling achievement of business results' ( } p \text {. } \\
259 \text { ) } \\
\text { - 'the very essence of engagement': the line of } \\
\text { sight between marketplace and each individual } \\
\text { (p. 260) } \\
\text { - all engagement must start at the same place - } \\
\text { reality' (p. 261) } \\
\text { - 'people who are engaged do not notice the }\end{array}$ & Strategic change \\
\hline
\end{tabular}




\begin{tabular}{|c|c|c|}
\hline & $\begin{array}{l}\text { passage of time-their hearts and minds are } \\
\text { involved, so time seems unimportant...It is } \\
\text { sustained connection and undivided } \\
\text { concentration (pp. 255-6) } \\
\text { (intellectual, emotional, behavioral) }\end{array}$ & \\
\hline Kahn (1990) & $\begin{array}{l}\text { Engagement } \\
\text { - 'in engagement, people employ and express } \\
\text { themselves physically, cognitively and } \\
\text { emotionally during role performances' (p. 694) }\end{array}$ & $\begin{array}{l}\text { Individual-level } \\
\text { performance } \\
\text { improvement }\end{array}$ \\
\hline $\begin{array}{l}\text { Kim \& } \\
\text { Mauborgne } \\
\text { (1993) }\end{array}$ & $\begin{array}{l}\text { Compliance through the attitudes of } \\
\text { commitment, trust, outcome satisfactions } \\
\text { (intellectual, emotional) } \\
\text { Identification with/Exertion of effort to achieve } \\
\text { strategic objectives (behavioral) }\end{array}$ & $\begin{array}{l}\text { Strategic buy- } \\
\text { in/strategy } \\
\text { implementation }\end{array}$ \\
\hline $\begin{array}{l}\text { Leana \& } \\
\text { Barry }(2000)\end{array}$ & $\begin{array}{l}\text { Social and occupational constructs of self } \\
\text { - create tension between the preference for } \\
\text { change and the need for stability } \\
\text { - individuals have tendencies to engage in } \\
\text { particular cognitive or behavioral strategies } \\
\text { (intellectual, emotional, behavioral) }\end{array}$ & Ability to change \\
\hline $\begin{array}{l}\text { Leana \& Van } \\
\text { Buren (1999) }\end{array}$ & $\begin{array}{l}\text { Engagement } \\
\text { - part of organizational social capital, 'the } \\
\text { character of social relations within the } \\
\text { organization, realized through members' levels } \\
\text { of collective goal orientation and shared trust'(p. } \\
540) \text { (emotional, behavioral) }\end{array}$ & $\begin{array}{l}\text { Adaptability to } \\
\text { change }\end{array}$ \\
\hline Lines (2004) & $\begin{array}{l}\text { Resistance, Commitment, Goal achievement } \\
\text { - change requires reduced resistance } \\
\text { (emotional), increased commitment (intellectual), } \\
\text { and goal achievement (behavioral) }\end{array}$ & Strategic change \\
\hline $\begin{array}{l}\text { May, Gilson, } \\
\text { \& Harter } \\
(2004)\end{array}$ & $\begin{array}{l}\text { Engagement } \\
\text { - involves the 'harnessing of organizational } \\
\text { members' selves to their work roles' ( } p .12) \\
\text { - 'differs from job involvement in that it is } \\
\text { concerned more with how the individual employs } \\
\text { him/herself during the performance of the job' ( } p \text {. } \\
\text { 12) } \\
\text { - 'entails the active use of emotions and } \\
\text { behaviours, in addition to cognitions' (p. 12) }\end{array}$ & $\begin{array}{l}\text { Organizational } \\
\text { performance } \\
\text { improvement }\end{array}$ \\
\hline $\begin{array}{l}\text { Meechan \& } \\
\text { Baschera } \\
(2002)\end{array}$ & $\begin{array}{l}\text { Employee morale } \\
\text { - measured as self-reported 'satisfaction' } \\
\text { - connected to employees' understanding of the } \\
\text { company's direction (intellectual) } \\
\text { - 'one of the key drivers of employee morale is } \\
\text { the confidence and respect employees, at every } \\
\text { level, have for their immediate bosses' (p. 35) }\end{array}$ & $\begin{array}{l}\text { Strategy } \\
\text { implementation }\end{array}$ \\
\hline
\end{tabular}




\begin{tabular}{|c|c|c|}
\hline Miles (2001) & $\begin{array}{l}\text { Emotional energy, Physical energy } \\
\text { - buy-in (intellectual) } \\
\text { - redefine behavior (behavioral) }\end{array}$ & \begin{tabular}{|l} 
Strategy \\
implementation
\end{tabular} \\
\hline $\begin{array}{l}\text { Newman } \\
\text { (1989) }\end{array}$ & $\begin{array}{l}\text { Engagement } \\
\text { - 'more than motivation or the general desire to } \\
\text { succeed...it involves participation, connection, } \\
\text { attachment, and integration in particular settings } \\
\text { and tasks' (p. 34) } \\
\text { - 'the opposite of alienation, isolation, } \\
\text { separation, detachment, and fragmentation' (p. } \\
\text { 34) } \\
\text { - 'in academic work is the student's } \\
\text { psychological investment in learning, } \\
\text { comprehending, and mastering knowledge or } \\
\text { skills' (p. 34) } \\
\text { (socio-emotional, intellectual, behavioral) }\end{array}$ & $\begin{array}{l}\text { Organizational and } \\
\text { individual-level } \\
\text { learning }\end{array}$ \\
\hline $\begin{array}{l}\text { Sanders, } \\
\text { Hopkins, \& } \\
\text { Geroy } \\
(2004)\end{array}$ & $\begin{array}{l}\text { Workplace spirituality } \\
\text { - the extent to which organizations encourage a } \\
\text { sense of meaning and interconnectedness } \\
\text { among their employees } \\
\text { - about acknowledging and developing the } \\
\text { employee as a 'whole person' ( } p \text {. A1) } \\
\text { (intellectual, socio-emotional, behavioral) }\end{array}$ & $\begin{array}{l}\text { Ability to sustain } \\
\text { competitive } \\
\text { advantage }\end{array}$ \\
\hline $\begin{array}{l}\text { Schaufeli \& } \\
\text { Bakker } \\
(2004)\end{array}$ & $\begin{array}{l}\text { Engagement } \\
\text { - 'a positive, fulfilling, work-related state of mind } \\
\text { that is characterized by vigor, dedication, and } \\
\text { absorption' (p. 295) } \\
\text { - 'refers to a persistent and pervasive affective- } \\
\text { cognitive state that is not focused on any } \\
\text { particular object, event, individual or behavior' } \\
\text { (p. 295) } \\
\text { (intellectual, emotional, behavioral) }\end{array}$ & $\begin{array}{l}\text { Organizational and } \\
\text { individual-level } \\
\text { performance } \\
\text { improvement }\end{array}$ \\
\hline $\begin{array}{l}\text { Scheimann } \\
\text { (2005) }\end{array}$ & $\begin{array}{l}\text { Engagement } \\
\text { - 'means that the hands, hearts and minds of } \\
\text { employees are deployed at full tilt to meet the } \\
\text { objectives of the business, serve customers, } \\
\text { create a caring culture, and produce quality } \\
\text { products and services' (p. 19) (intellectual, } \\
\text { emotional, behavioral) }\end{array}$ & $\begin{array}{l}\text { Organizational } \\
\text { performance } \\
\text { improvement }\end{array}$ \\
\hline Shaw (2005) & $\begin{array}{l}\text { Engagement } \\
\text { - is not about achieving everything, which is } \\
\text { what often happens when engagement resides } \\
\text { only at the vision statement level } \\
\text { - is not about 'pulling every lever', though there } \\
\text { are 'limitless factors that will affect engagement'; } \\
\text { have to reduce both organizational objectives }\end{array}$ & Strategic change \\
\hline
\end{tabular}




\begin{tabular}{|c|c|c|}
\hline & $\begin{array}{l}\text { and drivers to a few core aims } \\
\text { - leads to physical involvement (ownership) and } \\
\text { emotional involvement (commitment) } \\
\text { (emotional, behavioral) }\end{array}$ & \\
\hline $\begin{array}{l}\text { St-Arnaud } \\
\text { (2005) }\end{array}$ & $\begin{array}{l}\text { Engagement } \\
\text { - has } 2 \text { components: emotional and intellectual } \\
\text { - intellectual engagement is built through } \\
\text { knowledge; what are the challenges faced by } \\
\text { the industry and by this company? } \\
\text { - emotional engagement is critical for (restoring) } \\
\text { commitment; } 4 \text { core factors: } \\
\text { (1) relationships } \\
\text { (2) credibility } \\
\text { (3) respect } \\
\text { (4) putting people first (p. 19) }\end{array}$ & Culture change \\
\hline $\begin{array}{l}\text { Strayhorn } \\
(2004)\end{array}$ & $\begin{array}{l}\text { Engagement } \\
\text { - occurs on } 3 \text { levels: cognitive, emotional, } \\
\text { behavioral (4) } \\
\text { - creates motivation to learn }\end{array}$ & $\begin{array}{l}\text { Organizational and } \\
\text { individual-level } \\
\text { learning }\end{array}$ \\
\hline $\begin{array}{l}\text { Thatcher } \\
\text { (2005) }\end{array}$ & $\begin{array}{l}\text { Engagement } \\
\text { - an engaged employee is 'someone who } \\
\text { understands what the business is trying to } \\
\text { achieve and feels motivated to help make it } \\
\text { happen' (p. 2) (intellectual, behavioral) }\end{array}$ & $\begin{array}{l}\text { Organizational and } \\
\text { individual-level } \\
\text { performance } \\
\text { improvement }\end{array}$ \\
\hline $\begin{array}{l}\text { Voelpel, } \\
\text { Leibold, \& } \\
\text { Mahmoud } \\
(2004)\end{array}$ & $\begin{array}{l}\text { Organizational fitness } \\
\text { - includes commitment, communication, sense- } \\
\text { making (intellectual, behavioral) }\end{array}$ & $\begin{array}{l}\text { Change to meet } \\
\text { challenges }\end{array}$ \\
\hline Wolf (2004) & $\begin{array}{l}\text { Spiritual leadership } \\
\text { - 'emphasizes a high interest in ethics, values, } \\
\text { relationship skills, and promotion of the balance } \\
\text { between work and self' (p. 23) } \\
\text { - not a synonym for religion (p. 23) } \\
\text { - creates a more positive feeling about the } \\
\text { organization, a stronger sense of its values, a } \\
\text { deeper commitment to their employer and a } \\
\text { better understanding of themselves (p. 24) } \\
\text { (intellectual, emotional, behavioral) }\end{array}$ & $\begin{array}{l}\text { Organizational and } \\
\text { individual-level } \\
\text { performance } \\
\text { improvement }\end{array}$ \\
\hline $\begin{array}{l}\text { Woodruffe } \\
\text { (2006) }\end{array}$ & $\begin{array}{l}\text { Engagement } \\
\text { - is 'an employee being full intellectually and } \\
\text { emotionally committed to a particular job, so that } \\
\text { he or she wants to give to that job what is known } \\
\text { a discretionary effort' ( } p .29 \text { ) (intellectual, } \\
\text { emotional, behavioral) }\end{array}$ & $\begin{array}{l}\text { Organizational } \\
\text { performance } \\
\text { improvement }\end{array}$ \\
\hline
\end{tabular}


Table 1 summarizes this research. It presents each study's particular conceptualization of engagement and the underlying dimensions as well as the change-related outcome.

We developed two propositions that capture these findings. Our first proposition builds on the seminal work of Kahn (1990), Schaufeli and Bakker (2004) and others in defining engagement, and the second proposition makes explicit the connections between strategy formulation, implementation and engagement:

Proposition 1: The construct of engagement is most meaningfully constituted by the three dimensions of cognition (thinking), emotion (feeling) and action (behavior).

Proposition 2: Engagement facilitates the process by which formulated strategy is successfully implemented to effect organizational change.

\section{Social significance}

We argued previously that a specific kind of organizational context is needed to create an engaged workforce, one that provides what we labeled social significance:

Social significance speaks to the degree and range of the organization's influence on the individual, and concedes that organizations provide valuable social and emotional benefits in addition to economic ones. The term encompasses relationship, value congruence, trust, security, respect and integrity elements, many of which are believed to be integral to the development of employee engagement. (Haugen \& Davis, in press)

The academic engagement and spirituality studies provide insights that further support our model and especially enrich our concept of social significance. These studies, six of which are novel to this analysis, serve to reinforce the ideas that engagement has an explicit emotional dimension, that it is associated with outcomes that are critical to organizational and individual success, and that it is dependent upon a context of trust, safety/security, credibility and integrity. Particularly as engagement relates to learning and innovation, trust is imperative in encouraging the risk-taking that is vital to these processes and discouraging the fear of failure that paralyzes them. But these studies go further in identifying two other conditions: freedom of expression and spiritual leadership.

Developing the employee as a "whole person" (Sanders, Hopkins, \& Geroy, 2004, p. A1) and creating a workplace "where workers can bring their whole selves" (Dent, Higgins, \& Wharff, 2005, p. 640) is a focus that is also found in organizational behavior and organizational psychology literatures in their treatment of employee well-being, work-life balance and work-family facilitation (Grzywacz, Carlson, Kacmar, \& Wayne, 
2007; Ilies, Schwind, \& Heller, 2007; Moliner, Martinez-Tur, Ramos, Peiró, \& Cropanzano, 2008; Sendjaya, Sarros, \& Santora, 2008). Closely associated with a holistic employee orientation, freedom of expression is congruent with our concept of social significance and may be as important to the issue of sustainability as to development. Another perspective predicated on freedom of expression proposes that engagement is a choice shaped by one's workplace experiences (D'Aprix \& Tyler, 2006). Choice is driven by a slate of accrued experiences which vary as a function of authority or position in the organization. For lower-level employees, choice is rather deterministic in that it is shaped primarily by factors outside of their immediate control (e.g., culture, leadership, strategy, job characteristics). Leaders and managers also assess their experiences in these terms but add to the calculation variables like personal risk, reward and accountability. Inclusion of these factors makes it clear that upper-echelon actors actually possess some influence over their own workplace experience and raises the question of whether an authentically engaged workforce can be developed where influence is not widely shared.

Other evidence supports the idea that granting to employees - not just to leaders and managers - some degree of discretion over meaningful aspects of their work is associated with satisfaction in work and non-work roles alike (Haugen, 2006), another way to describe the realm of the whole person. Ownership is a related term, defined as providing the rights that allow individuals to take control (Pierce, Kostova, \& Dirks, 2001). Thus, incorporating the ideas of ownership and individual discretion or autonomy into our model of engagement may provide a better explanation of the process through its fuller characterization of social significance.

Principal differences between this group of studies and our own work relate to the organization of the engagement process. On the one hand, these articles suggest that the social or physical dimension is an integral aspect of engagement, whereas our model places relationships in a contextual or supporting position - without a foundation of socially significant relationships, engagement will be very difficult to develop and impossible to sustain. On the other hand, these literatures understand cognition as something that happens as a result of engagement, and not, as we contend, as inseparable from the intellectual-emotional-behavioral process that constitutes engagement. While the differences are important, underscoring that each perspective provides a unique understanding, the significant similarities provide fertile ground for confirming and extending our initial work.

A few additional variables bolstered our model. One idea is suggested by concepts of psychological meaningfulness, sense of significance and dedication (Gubman, 2004; Kahn, 1990; May, Gilson, \& Harter, 2004; Schaufeli, \& Bakker, 2004). In these studies, the terms are similar in referring to the meaning or value derived from one's work and are related to job enrichment, work role fit, and coworker relations. Our social significance construct already captures directly the relations aspect of meaningfulness, and value congruence can be argued to subsume work characteristics, especially the idea of work role fit. Nonetheless, the nature of work has a natural place in a model that puts the individual on par with the organization, and making it an explicit component 
strengthens our model's explanatory power. Additionally, a focus on this aspect is consistent with the demands on managers to tailor jobs to individual capabilities rather than assign off-the-rack roles and responsibilities (Buckingham, 2005; Dychtwald, Erickson, \& Morison, 2006; Kalleberg, 2008), an issue we take up below.

Psychological availability is a second idea that may have merit for our model. May, Gilson, and Harter (2004) propose that physical, cognitive and emotional resources are associated with engagement through their effect on individuals' psychological availability or mental receptiveness to their work. Specific resources include work role security and outside activities. Security or safety already has a place in the model's foundation but not the notion of outside activities. We find the same idea in a study of student engagement in high schools where extra- and co-curricular activities such as music events, athletic programs and student advising are posited to provide a "sense of caring" central to the development of trust (Newman, 1989, p. 35). Trust in turn works to facilitate risk-taking and mitigate fear of failure, ideas discussed earlier, thereby stimulating engagement, learning and innovation. Trust, risk and fear are all concepts taken into account by our model through the social significance construct, but these studies provide the insight that engagement may be fostered by creating organizational opportunities for expressing genuine care and concern; something beyond the annual company picnic or Christmas party is envisioned.

A final consideration comes from Huy's (2002) study of the role of emotion in radical change. In our prior paper, we defined emotion in terms of affect and attraction and related the formation of preference to positive and negative emotional states. We argued that change emanates from the interaction of all three dimensions: the emotional preference for the change, the intellectual conviction that the change is the right course of action, and the behavior itself, combine to lead actors into collective action that is consistent with the organization's needs (Haugen \& Davis, in press). Huy's research provides a deeper analysis of emotion and we can fruitfully incorporate some of these elements into our framework. Freedom to express authentic feelings, a theme found also in the spirituality literature, explicitly encompasses here the ideas of empathy, sympathy, encouragement, hope, fun, and even love. Recognizing that emotion in the workplace can be intense at both extremes enriches our construct at the same time that it makes it clear how radical the concept of engagement really is and thus how difficult it is to develop. Our third proposition broadly summarizes these ideas and insights:

Proposition 3: Social significance characterizes an organizational context of valuable reciprocal relationships psychological, social and emotional as well as economic and provides the necessary foundation for authentic engagement.

Based upon the foregoing analyses and propositions, Figure 1 represents our elaborated model of engagement. It confirms that engagement is a three-component construct that contributes to organizational performance through its impact on strategy 
implementation and further qualifies the foundational basis of the process relative to our earlier endeavor.

Figure 1. Refined Model of Engagement: Role in Strategy Implementation

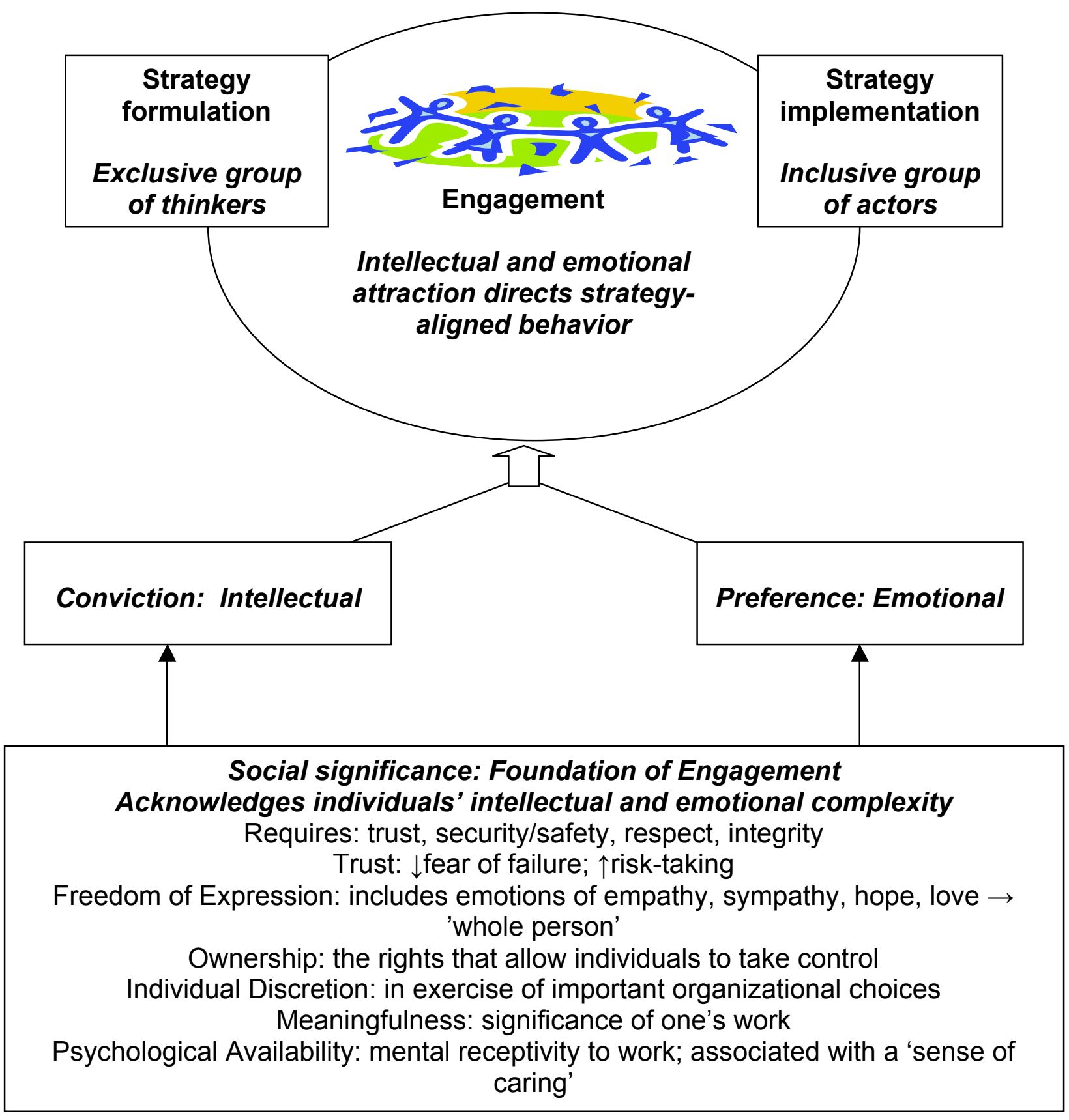




\section{Toward Developing Engaged Employees}

In addition to these findings, the study also importantly informed a related issue, how to develop and/or sustain engagement. Seven additional studies, included in this research because they advanced Appreciative Inquiry ( $\mathrm{Al}$ ) as an approach to effecting organizational change initiatives, supported our prior position on the close alignment between this methodology and the development of engagement. A reconfiguration of conventional action-research that deemphasizes the 'action' part and reemphasizes the 'research' part, Al provides a methodological bridge for reconnecting theory and practice. It is a narrative approach that affirms individual and collective efforts by focusing on positive questions and as such, is particularly effective in bringing about organizational transformation (Cooperrider \& Srivasta, 1987).

We maintained that there was a strong connection between storytelling as a type of narrative and Al organizational change efforts, and this relationship is borne out in the present analysis. Storytelling is identified as an Al approach that is linked to sustaining engagement in order to sustain the organization's momentum. It is key to easing "change fatigue," to generating energy and ownership, and to helping humanize and clarify strategy so that everyone in the organization can understand it and participate in the change process (Jackson \& Esse, 2006, p. 26). Al also "sets up a willingness to be involved" in culture change efforts and releases the creativity and development potential of the organization by unlocking the collective intelligence and experience of its workforce (Berrisford, 2005, p. 25).

The Al literature also provides some novel insights that we can appropriate for our model. Buckingham (2005) notes that Al's emphasis on identifying strengths is consistent with an emphasis on valuing the unique abilities, even the eccentricities, of employees. The implications relate primarily to management and suggest that the chief challenge is to comprehend the complexity inherent in each employee and structure work that reflects this complexity; the game of chess rather than checkers is the appropriate management metaphor (Buckingham, 2005). The role of the manager as deeply involved in assessing individuals' capabilities and creating fulfilling work is highly congruent with our model of engagement and its focus on the needs of both parties to the exchange. Developing an engaged workforce will depend on first developing managers with the requisite skills to recognize unique value and customize context.

Secondly, we note the related issues of emotional labor and emotional management, both of which are concerned with individuals' attempts to manage their emotions in order to preserve the proper reactions of others (Horrocks \& Callahan, 2006; Turnbull, 1999). When suppression of true feelings is involved, costs arise from individuals striving to create a false sense of self. Over time, disguising felt emotion has been connected to personal disharmony, depression and even death (Clark, 2001; Krone, Chen, Sloan, \& Gallant, 1997, in Horrocks \& Callahan, 2006). At the other end of the continuum, a lack of emotional constraint is likewise costly to the individual and others, as self-identity suffers and relationships are overwhelmed by unrelenting drama and passion. With its explicit emotional dimension and the value it places on the freedom of 
individual expression, engagement must be concerned with these issues and aware of their costs. Other studies (e.g., Hochschild, 1983; Horrocks \& Callahan, 2006; Turnbull, 1999) have found that moderation in emotion management represents a functional balance between emotion and self, reducing the potential for false expression and encouraging the development of stable identity. Adopting this goal of moderation for our process model also would seem to be a reasonable proposal.

Our fourth and final proposition expresses these findings related to development:

Proposition 4: The development of engagement is associated with increased demands on leaders and managers to deal with increased emotional complexity of work and workforce alike; and with Appreciative Inquiry as an effective methodology that humanizes and clarifies strategy and facilitates the full involvement of the organization's membership.

\section{Discussion}

In the current context, we believe that leadership and management roles, perhaps especially those of human resources professionals, will assume a growing importance in creating an engaged workforce. With accelerating rates of technological change and market integration in combination with rising customer sophistication, all of which impact more and more firms and industries, customer service has become an increasingly important source of meaningful differentiation and competitive advantage. Effective customer service depends fundamentally on relationships both within and without the organization. Accordingly, business models have shifted from an efficiency-motivated transactional basis to a service-motivated relational basis. The organizational contract, too - the set of inducements and contributions that constitutes the understanding between organization and employee - has had to change to reflect this reality. And the currency of engagement has risen because of its particular fit with these broader shifts.

Successfully building and sustaining relationships requires that employees invest their hearts and souls in addition to their minds and bodies, a dramatic departure from the traditional understanding of exchanging intellect and effort for primarily financial inducements. Opening up this box allows messy human emotions to legitimately permeate the environment and become topics of discussion - of policy, procedure, performance - complicating the traditional exchange to an extent for which most organizations are wholly unprepared. The potential for disengagement and the fallout in general from breaching the new contract in the process of trying to develop a relational organization pose serious threats to both individuals and organizations. Leaders and managers in this environment will assume even more importance in driving organizational performance and they must be the first to learn new sets of predominantly tacit skills and approaches in order to effectively lead and manage others to do the same. 
Another challenge to development is suggested by the "dark side" theme, wherein efforts to build engagement are perceived as exploitative. The potential for exploitation and manipulation exists in engagement research as it does in much of the organizational behavior research in general; the suspicion is that efforts to develop engagement, although promoted as enhancing job satisfaction and quality of work life, instead provide a management intervention tool for singularly extracting greater employee effort. When expectations of work-life balance, reciprocity and mutual gain are not realized for whatever reason, the relational foundation of the organization - our social significance construct - is inevitably weakened; because trust, integrity, security and respect are compromised, so too are the relationships that are built on these bases. The development of something as complex and ambitious as engagement then becomes impossible.

Organizations therefore need to be scrupulous in avoiding both the substance and appearance of manipulation. For example, promoting "absorption" - the state in which one is "fully concentrated and happily engrossed in one's work where time passes quickly and one has difficulties detaching from work" (Schaufeli \& Bakker, 2004, p. 295) - as an individual-level benefit of engagement may raise questions about whose interests are principally being served. And efforts to increase members' organizational identity in order to engender greater willingness to modify their own behavior to support organizational change (Dutton, Dukerich, \& Harquail, 1994), is likewise open to perceptions of imbalance. Transparency in the engagement process should help to ensure that organizational and individual outcomes are mutually valuable. Appreciative Inquiry with its emphasis on participation in organizational change initiatives holds particular promise for achieving this objective.

\section{Conclusion}

We maintain that most individuals desire to be emotionally and intellectually invested in their work, and that organizations that recognize this need and find a way to develop a context that cultivates and supports it stand to create a unique source of advantage for themselves and their employees. With this model of engagement, we are hopeful that we have provided a viable position from which to have continued discussion as well empirical evaluation and theory development. The benefits from reconnecting strategic thinking and doing that accrue to both organizations and individuals are significant and, we believe, more than justify the necessary investments.

\section{References}

Beer, M., Eisenstat, R., \& Spector, B. (1990). Why change programs don't produce change. Harvard Business Review, 68, 158-166.

Berrisford, S. (2005). Using appreciative inquiry to drive change at the BBC. Strategic Communication Management, 9, 22-25.

Buckingham, M. (2005). What great managers do. Harvard Business Review, 83, 70-79. 
Bruch, H., \& Sattelberger, T. (2001). The turnaround at Lufthansa: Learning from the change process. Journal of Change Management, 1, 344-363.

Bruch, H., Gerber, P., \& Maier, V. (2005). Strategic change decisions: Doing the right change right. Journal of Change Management, 5, 97-107.

Clark, M. C. (2001). Incarcerated women and the construction of self. In R. M. Cervero, B. C.Courtenay, \& C. H. Monaghan (Eds.), Global research perspectives (pp. 1427). Athens, GA: The Cyril O. Houle Scholars in Audit and Continuing Education Program, University of Georgia.

Cooperrider, D. L., \& Srivasta, S. (1987). Appreciative inquiry in organizational life. In R. Woodman \& W. Pasmore (Eds.), Research in organizational change and development (1, pp. 129-169). JAI Press.

D’Aprix, R., \& Tyler, C. F. (2006). Four essential ingredients for transforming culture. Strategic Communication Management, 10, 22-25.

Dent, E. B., Higgins, M. E., \& Wharff, D. M. (2005). Spirituality and leadership: An empirical review of definitions, distinctions, and embedded assumptions. Leadership Quarterly, 16, 625-653.

Dutton, J. E. Dukerich, J. M., \& Harquail, C. V. (1994). Organizational images and member Identification. Administrative Science Quarterly, 39, 239-263.

Dychtwald, K. Erickson, T.J., \& Morison, R. (2006). Workforce crisis: How to beat the coming shortage of skills and talent. Boston, MA: Harvard Business School Press.

Gould, S. (1979). An equity-exchange model of organizational involvement. Academy of Management Review, 4, 53-62.

Grzywacz, J. G., Carlson, D. S., Kacmar, K. M., \& Wayne, J. H. (2007). A multi-level perspective on the synergies between work and family. Journal of Occupational and Organizational Psychology, 80, 559-574.

Gubman, E. (2004). From engagement to passion for work: The search for the missing person. Human Resource Planning, 27, 42-46.

Harley, A., \& Lee, D. (2005). How 02 built the business case for engagement. Strategic HR Review, 4, 24-27.

Haudan, J. A., \& MacLean, D. (2002). "E" is for engagement: Transforming your business by transforming your people. Journal of Change Management, 2, 255265. 
Haugen, L. K. (2006). The case for complexity: A look at the relationship between individual and structure from the inside out. Human Resource Development International, 9, 49-67.

Haugen, L.K., \& Davis, A.S. (in press). Bridging the thinking-doing divide: Engaged in strategy implementation. International Journal of Learning and Intellectual Capital.

Hochschild, A. R. (1983). The managed heart: Commercialization of human feelings. Berkeley, CA.: University of California Press.

Horrocks, A., \& Callahan, J. L. (2006). The role of emotion and narrative in the reciprocal construction of identity. Human Resource Development International, 9, 69-83.

Huy, Q. (2002). Emotional balancing of organizational continuity and radical change: the contribution of middle managers. Administration Science Quarterly, 47, 31-69.

Ilies, R., Schwind, K. M., \& Heller, D. (2007). Employee well-being: a multilevel model linking work and nonwork domains. European Journal of Work \& Organizational Psychology, 16, 326-341.

Jackson, S., \& Esse, A. (2006). Making a difference through storytelling at Parcelforce. Strategic Communication Management, 5, 26-29.

Kahn, W. (1990). Psychological conditions of personal engagement and disengagement at work. Academy of Management Journal, 33, 692-724.

Kalleberg, A.L. (2008). The mismatched worker: When people don't fit their jobs. Academy of Management Perspective, 22, 24-40.

Kim, W. C., \& Mauborgne, R. A. (1993). Procedural justice, attitudes, and subsidiary top management compliance with multinationals' corporate strategic decisions. Academy of Management Journal, 36, 502- 526.

Krone, K., Chen, L., Sloan, D., \& Gallant, L. (1997). Managerial emotionality in Chinese Factories. Management Communication Quarterly, 11, 6-50.

Leana, C., \& Barry, B. (2000). Stability and change as simultaneous experiences in organizational life. Academy of Management Review, 25, 753-759.

Leana, C. R., \& Van Buren, H. (1999). Organizational Social Capital and Employment Practices. Academy of Management Review, 24, 538-555. 
Lines, R. (2004). Influence of participation in strategic change: Resistance, organizational commitment and change goal achievement. Journal of Change Management, 4,193-215.

May, D., Gilson, R., \& Harter, L. (2004). The psychological conditions of meaningfulness, safety and availability and the engagement of the human spirit at work. Journal of Occupational and Organizational Psychology, 77, 11-37.

Meechan, S., \& Baschera, P. (2002). Lessons from Hilti: How customer and employee contact improves strategy implementation. Business Strategy Review, 13, 31-39.

Miles, M. B. \& Huberman, A. M. (1994). An expanded sourcebook: Qualitative data analysis $\left(2^{\text {nd }} E d.\right)$. Thousand Oaks, CA.: Sage.

Miles, R. H. (2001). Beyond the age of Dilbert: Accelerating corporate transformations by rapidly engaging all employees. Organizational Dynamics, 29, 313-321.

Moliner, C., Martinez-Tur, V., Ramos, J., Peiró, J. M., \& Cropanzano, R. (2008). Organizational justice and extrarole customer service: the mediating role of wellbeing at work. European Journal of Work \& Organizational Psychology, 17, 327348.

Neal, J., \& Biberman, J. (2003). Introduction: the leading edge in research on spirituality and organizations. Journal of Organizational Change Management, 16, 363 366.

Newman, F. M. (1989). Student engagement and high school reform. Educational Leadership, February, 34-36.

Pierce, J. L., Kostova, T., \& Dirks, K. T. (2001). Toward a theory of psychological ownership in organizations. Academy of Management Review, 26, 298-310.

Sanders, III, J. E., Hopkins, W. E., \& Geroy, G. D. (2004). Spirituality-leadershipcommitment relationships in the workplace: An exploratory assessment. Academy of Management Proceedings Best Conference Paper, pp. A1-A6.

Schaufeli, W. B., \& Bakker, A. B. (2004). Job demands, job resources, and their relationship with burnout and engagement: A multi-sample study. Journal of Organizational Behavior, 25, 293-315.

Schiemann, W. A. (2005). Measuring return on human capital: Build the equity of your people. Leadership Excellence, 22, 19.

Sendjaya, S., Sarros, J. C., \& Santora, J. C. (2008). Defining and measuring servant leadership behaviour in organizations. Journal of Management Studies, 45, 402424. 
Shaw, K. (2005). An engagement strategy process for communicators: Clarifying what engagement means for your organization. Strategic Communication Management, 9, 26-29.

St-Arnaud, L. (2005). Engaging to improve results at Bombardier: Placing managers and leaders at the heart of employee engagement. Strategic Communication Management, 9, 18-21.

Strauss, A. \& Corbin, J. (1998). Basics of qualitative research: Techniques and procedures for developing grounded theory ( $2^{\text {nd }} \mathrm{Ed}$.). Thousand Oaks, CA.: Sage.

Staw, B. M., Sutton, R. I., \& Pelled, L. H. (1994). Employee positive emotion and favorable outcomes at the workplace. Organization Science, 5, 51-71.

Strayhorn, T. L. (2004). Engaging schools: Fostering high school students' motivation to learn. [Review] National Research Council and the Institute of Medicine, September 27, Washington, DC: The National Academies.

Thatcher, M. (2005). Employee engagement is about braincount vs. headcount. Strategic Communication Management, 9, 2.

Turnbull, S. (1999). Emotional labour in corporate change programmes: The effects of organizational feeling rules on middle managers. Human Resource Development International, 2, 313-335.

Voelpel, S. C., Leibold, M., \& Mahmoud, K. M. (2004). The organizational fitness navigator: Enabling and measuring organizational fitness for rapid change. Journal of Change Management, 4, 123-140.

Wolf, E. J. (2004, March/April). Spiritual leadership: A new model. Healthcare Executive, 19(2), 23-25.

Woodruffe, C. (2006). Employee engagement: The real secret of winning a crucial edge over your rivals. British Journal of Administrative Management, 50, 28-29. 